\title{
Performance and politics of authenticity in live ethnographic exhibitions
}

\author{
Anne Folke Henningsen
}

\begin{abstract}
In the summer 2010 a small group of Namibians visited Denmark in order to present and disseminate knowledge of the so-called Bushman culture in an experimental archaeological park outside Copenhagen. The staging of the event was in many ways similar to the kind of display that has been termed "human zoo" or "live ethnographic exhibition", so popular in the nineteenth and early twentieth centuries, but there were also significant differences to be found. The discourse of cultural and racial authenticity that informed the live ethnographic exhibitions a hundred years ago was also called upon in the performances in 2010. However, the political and to a certain extent the exhibition contexts were different, as were the possibilities of appropriating long-lasting and pervasive ideas of "Bushman-ness" to various political ends. In this article, the effects of the recent recurrence of this practice of live ethnographic exhibitions are analysed through concepts such as authenticity and coevalness and their wider political potentialities are discussed. ${ }^{1}$
\end{abstract}

Keywords: Live ethnographic exhibitions, authenticity, ethno-politics, San people, Sagnlandet Lejre.

In late July 2010 I was hiking in Norway when my vacation was interrupted by urgent messages from colleagues directing my attention to and asking my opinion on an event in the experimental archaeological park Lejre outside Copenhagen. At the time I was carrying out a collaborative research project on live ethnographic exhibitions of so-called exotic people in Copenhagen in the decades around 1900 (see Andreassen \& Henningsen 2011). The event at Lejre, which was centred upon the participation of three so-called Bushmen from Namibia in a Stone Age festival, seemed to somehow mimic some of the practices of old - as one colleague put it when forwarding me information about the event: "Look, displays of savages still exist." ${ }^{2}$

Intrigued, I cut my holiday short and made it to Lejre on the very last day of the event without opportunity for much preparation in terms of setting up interviews or contacting the organisers. The ensuing fieldwork was thus both spontaneous and heavily informed by my ongoing studies of historic configurations of exotic bodies put on display.

The following article is mainly based on my 
field notes, observations and readings of the event in Lejre that had so upset my colleagues and me. It also contains a discussion of strategic and political potentials of putting one's own body on display, which has resulted in a slight reconsideration on my part of both the historical and the recurrent spectacles. Thus, there is and has been an ongoing conversation between the two fields - the historical practice of putting bodies on display for ethnographic entertainment and education and the recurrent version in Lejre - which in turn have destabilised some of my previous assumptions and conclusions, if only to a certain extent, and provided me with a more nuanced view on the phenomenon at hand.

The venue for this visit from southern Africa to Denmark requires a few words of introduction. The experimental archaeological park at Lejre outside Copenhagen was established in the mid-1960s with the aim of creating a space in which the distant Danish and European past - what is often termed "prehistory" - could be brought to life through experiments and hands-on experiences for the visitors. As presented in the mission statement of the park: "The mission of Sagnlandet Lejre is to produce and disseminate knowledge and wonderment about the way of life in the past through experimental archaeological research, re-enactment and teaching based on active participation." (Internet source 1) Thus, with its population of professionals and amateurs experimenting with and re-enacting the cultures of the European Stone, Bronze and Iron Ages, visitors will always be expecting something out of the ordinary twenty-firstcentury behaviour upon entering the park: Men, women and children donning animal skins, grinding flour on rocks, spinning and dyeing wool, cooking over an open fire, and shooting with bows and arrows are all partaking in the attempt to bring the past to life before the eyes of the public and create an atmosphere of authenticity and ancient times. But on these summer days in 2010 new types of bodies were participating in the spectacle. A small group - three men and a woman - from Namibia had come to display the ancient ways of the so-called "Bushmen". One man was of German-Namibian descent, the rest of the group belonged to the San group Ju/'hoansi, and it was the culture of the latter that the visitors from far away had come to present to the Danes and the visiting tourists in the park at Lejre. The term "Bushman" is controversial due to its roots in colonial southern Africa, where so-called Bushmen were considered to be at the very bottom of the evolutionary hierarchy and not necessarily fully human; a hierarchical taxonomy with catastrophic consequences for the so-called Bushmen. In the mid-twentieth century the word San was coined by anthropologists to replace the tainted word Bushman, but this construct is also subject to controversy and there are differences in which group denominator individuals and sub-groups prefer; most use more specific terminology referring to the sub-group in question - in this case Ju/'hoansi. Using the term "Bushmen" rather than the more precise Ju/'hoansi can be argued to evoke certain pre-existing assumptions in the audience of encountering an exotic "natural" people, a point I shall return to later.

The group's German-Namibian man with his long beard and heavy-set white body easily blended in with the regular European performers of distant European pasts at the Lejre park. The small, brown-bodied Ju/'hoansi, however, stood markedly out. The German-Namibian had donned a long leather shirt in the style of the European performers in the park, whereas the Ju/'hoansi all were 
wearing loincloths, and strings of pearls wrapped around their upper bodies. The performance of the group was organised so that the German-Namibian acted as interpreter and gave a daily lecture on the "Bushman" way of life. The Ju/'hoansi were supposedly acting as themselves.

At Athra, the Stone Age section of the park, a small beehive hut of straw had been built, outside which the Ju/'hoansi performed supposedly everyday tasks of jewellery making and manufacturing of bows and arrows. Throughout the day activities meant to represent the "Bushman" way of life were scheduled, such as staged hunting expeditions, shooting with bows and arrows and skinning and cutting of wild boars. The GermanNamibian would translate the explanations of the Ju/'hoansi of their actions from Afrikaans into English and answer questions from the audience.

In this article I will take the living bodies of the displayed people as my point of departure and reflect on the specific meanings and effects of exhibition practices involving the particular kind of subject-object that exhibited living human bodies make up (cf. Henningsen 2010). First, I will draw lines back in time to earlier instances of live ethnographic exhibitions in Denmark to set the stage for the analysis of the more recent occurrence, and to present the lenses I was viewing the event in Lejre through when conducting the fieldwork there. Following this historical section, I will present contemporary contexts of the event in Lejre, particularly regarding the Namibian cultural, economic and political situation in which the Ju/'hoansi live and which informs their intentions and agendas in coming to Lejre, but also the rationalities behind the show in Lejre as seen from the point of view of the Danish organisers. The main

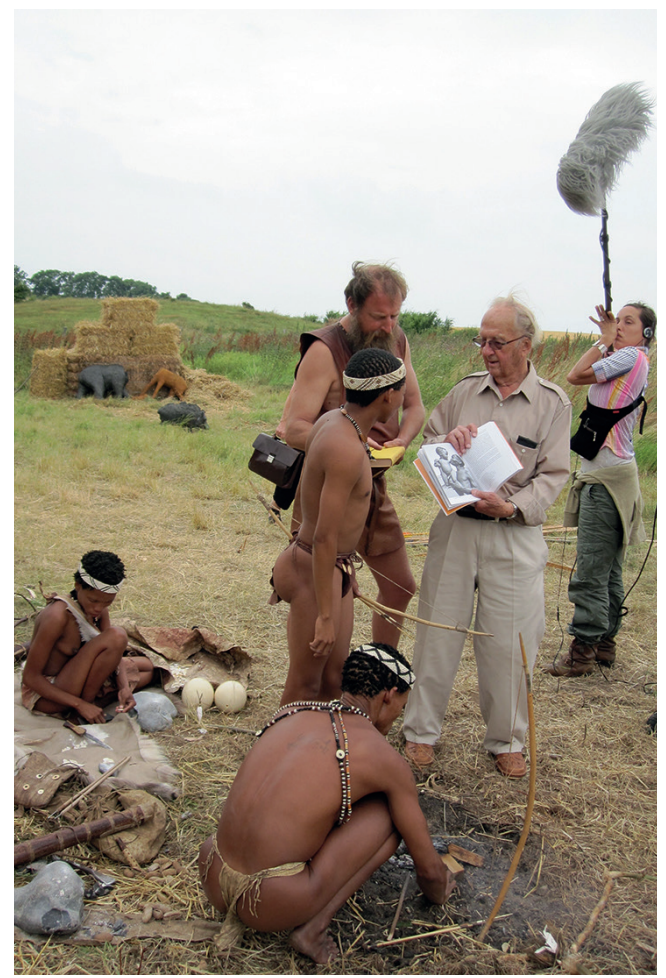

Fig. 1. Namibian performance in Lejre 2010. The three Ju/'hoansi-San people /Aao Nlaici, Khaum Ilóce and Tciixo Carisa and the German-Namibian Werner Pfeifer receive a visit from the Danish explorer Jens Bjerre at their camp in the Stone Age section Athra in Lejre. Photo: Anne Folke Henningsen 2010.

analytical part deals with the subject-object relations in the exhibitions, leading towards the concluding points about the ambiguous political potentials of the powerful invitation the staging of the living "Bushmen" bodies extended to the public at Lejre; an invitation to understand the performance and performers within what I have termed - in accordance with the terminology of, for example, Hylton White (1995) - the discourse of "The Eternal Bushman". 


\section{Previous live ethnographic EXHIBITIONS IN DENMARK}

The Zoological Garden and the amusement park Tivoli were the main venues for larger ethnographic exhibitions in Denmark from the 1870s until around 1905. Around 50 exhibitions of different so-called exotic people were organised in this period and they were hugely popular with the Danish public and press. Though apparently very similar, the event in Lejre was in many ways different from the earlier practices of live ethnographic exhibitions, as will be discussed later, but in order to fully grasp the implications of the Lejre event it is necessary to see it in the context of these earlier displays of "exotic" Others in Denmark. In such live ethnographic shows, the bodies of the exhibited people were central nodes of meaning production: In often elaborately staged settings they conveyed the sense of foreignness and difference that was the raison dêtre of the exhibitions (Henningsen 2009).

The main figure in the European and American human exhibitions of this type in the late nineteenth century was the German Carl Hagenbeck, who used his worldwide networks in the exotic animal trade to put together interesting groups of exotic people for display in zoos, amusement parks and other similar venues. These troupes would often circulate in Europe and North America for several months or even years, and Copenhagen was a frequent stop on the circuit. A central feature of the Hagenbeck style of live ethnographic exhibitions was his claim to the supreme authenticity of his troupes, in stark and explicit contrast to, say, the self-professed master of "humbug" P.T. Barnum in America. The claim was backed by collaboration with leading anthropologists of the time as well as somewhat paradoxically - the elaborate staging of the shows designed to provide the spectator with an experience of all-encompassing cultural and racial difference. Professor of German cultural studies Eric Ames, in his comprehensive study of Hagenbeck's Empire of Entertainment, describes the exercise in the following terms:

Choreographing authenticity was of course a contradictory task, which called for discursive backup. However much native performers were trained on the job, however much they were perceived to be performing, Hagenbeck would predicate their "authenticity" on the assertion that they were untaught, and therefore perfectly qualified for ethnographic display. In order to situate them as part of a living habitat, Hagenbeck and his team used various techniques for coding performers both discursively and iconographically as living, breathing "signs of themselves" (Ames 2008:75).

Ames thus points to the centrality of the living bodies in the claim of authenticity carrying the attraction of live ethnographic exhibitions as well as legitimising them as a superior genre of popular education and instruction for the Europeans about peoples of the rest of the world. This is along the lines of what professor of performance studies Barbara Kirshenblatt-Gimblett calls a foregrounding of presentation rather than representation, which in this case could be translated into claims of the exhibitions of showing real lived/ embodied life rather than staged ethnographic theatre (Kirshenblatt-Gimblett 1998) - even if the performances were heavily framed and choreographed.

In accordance with the Hagenbeck style of authenticity and the ethnographical popular education ensuing from it, the exhibitions sought to produce in the audience a sense of bodily difference from the people on display 


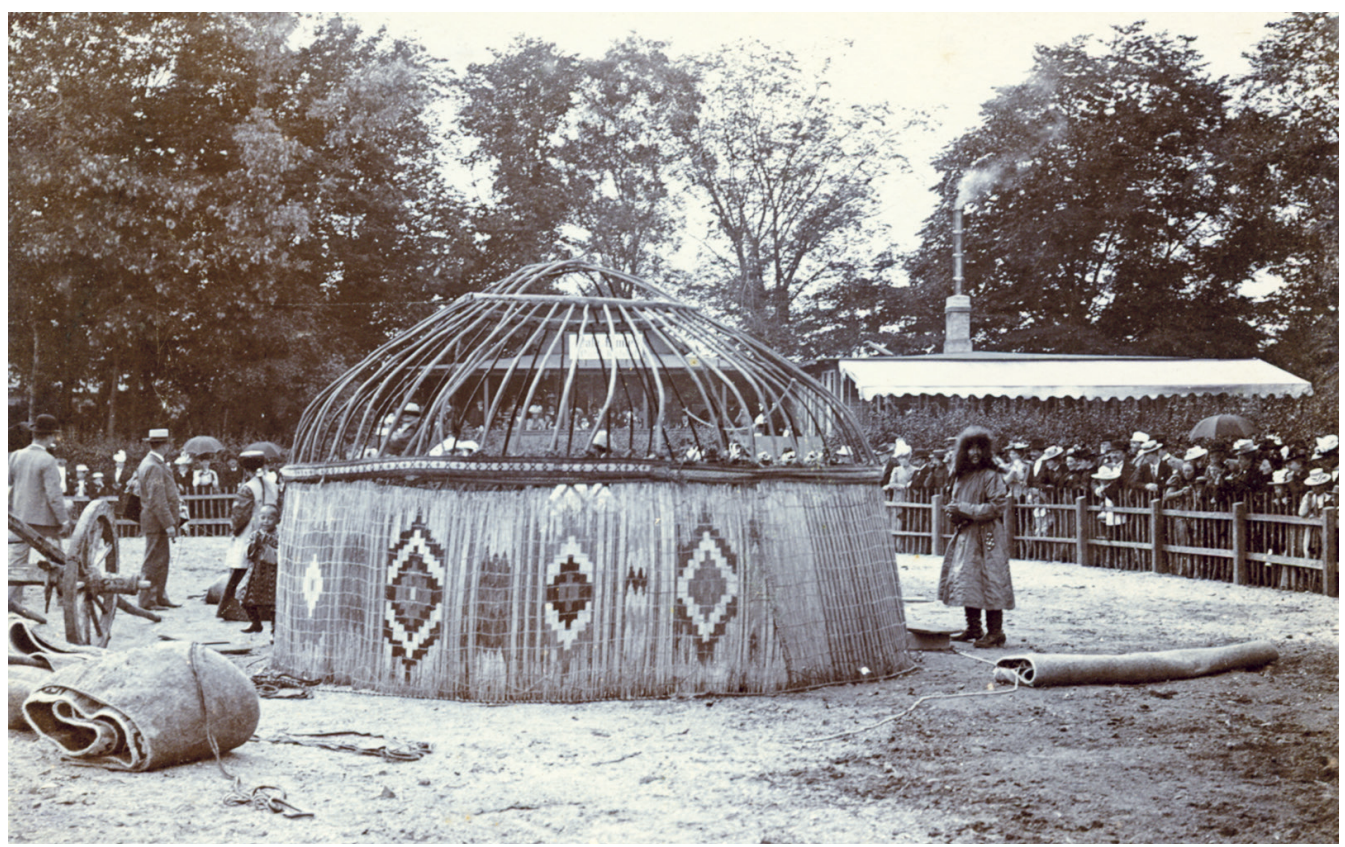

Fig. 2. The Kirghiz exhibition in Copenhagen Zoological Garden 1900. Part of the spectacle was the nomadic lifestyle of the Kirghiz and thus the public was invited to witness the setting up of their large tents in the Zoo. Photo: Archive of the Copenhagen Zoological Garden.

which was similar to that of the related genre of freak shows (cf. Garland-Thompson 1996) but with a very important difference: whereas the so-called freaks were put on stage to present their deviance from the norm, the bodies performing difference in the ethnographic exhibitions were displayed in order to represent their typicality (Ames 2008:71), albeit precisely their different typicality.

The exhibitions in Copenhagen were also operated and organised along these lines of thinking, whether directly part of Hagenbeck's repertoire or not, and displays of embodied, racialised authenticity were in high demand with the Danish audiences. Many are the newspaper reports describing and evaluating the exhibitions in terms of the superior authenticity of the troupes on display - or the problematic lack of convincing displays to back the claims to authenticity (cf. Henningsen 2009). Quite a few of these were directly linked to what was understood to be the authentic and immanent difference of the spectacular bodies to be seen in the shows. Two examples will suffice, both of which are focused on perceptions of inherent differences in bodily capability between the people on display and the Danish spectators.

In a leading Danish newspaper in which the different live ethnographic exhibitions enjoyed a fair amount of attention, the reporter Waldemar Dreyer, who reviewed many of the exhibitions at the Zoological Garden and later, in 1910, took up the position as director of the Zoo, explained what he understood to be the sensory deficiency of the central Asian 
Kirghiz, as represented by the troupe visiting Copenhagen Zoo in 1900:

Upon entering one of the Kibitkas and letting the curtain drop behind you, you have as vivid a picture of Kirghiz life as you can wish for. [...] The surroundings are loud and colourful in the cosy room, because strong colours, often harshly juxtaposed, appeal to the eyes of the less developed and less "cultivated" person. His nerves are not as susceptible as ours, so the influences must be strong to make an impression on him. [...] The same can be said of his music: thundering drums, screeching tambourines, jingling strings, and rattling nicknack, that is as far as his wishes go. [...] the low, melodious [music], which appeals to our more finely-tuned ears, leaves him completely untouched (Dreyer 1900, my translation).

In the same newspaper, one year later, the pseudonym Moustache described the incredible acts of the performers of the Asian Indian exhibition at the Zoo:

Absolutely wonderful are the balancing acts shown by the Indians on the top of a swaying bamboo pole planted in the centre of the stage. A perfectly monkey-like agility, to which you would find no match in European acrobatics ("Moustache" 1901, my translation).

Again, the central feature is how the bodies of the performers differ from those of the European spectators - by being seen as either anatomically under-evolved or almost animallike.

\section{AUthenticity AND Denial of COEVALNESS}

The concept of authenticity has been at the centre of anthropological research almost since its inception, albeit in different ways over time, and a recent publication entitled Debating Authenticity suggests that discussions of the concept are still very much alive in academia (Fillitz \& Saris 2012). The early anthropologists were anxious to get a sense of the "real" culture of the people they studied, that is, a culture untainted by Western ideas and practices. The futility and not least the problematic effects of this search for the pure and untainted cultures of what was often at the time called primitive societies has in turn been criticised since at least the 1980s, when anthropologists Johannes Fabian (1983/2002) and James Clifford (1988) - to name but two influential scholars published books deconstructing the practice of the anthropological communities with particular attention to the effects of notions of authenticity and stasis.

Thus, ideas such as those described above of authentic and essential bodily - as well as cultural - difference that was staged in live ethnographic exhibitions had consequences beyond the amusement parks. In her study of Aboriginal people in North America and Canada in the late nineteenth century historian Paige Raibmon states: "The notion of a singular Aboriginal culture - a culture that could be preserved in the static representations of ethnographic texts, museum cases, or stylized performances - held Aboriginal people to impossible standards of ahistorical cultural purity" (Raibmon 2005:9).

According to Raibmon the casting of people as "authentic", for instance in live ethnographic exhibitions, has far-reaching effects in the understanding of such people as ahistorical and unchanging beings - always under threat from the imminent danger of losing their authenticity by not living up to the ethnographically prescribed features of their culture, from themselves: "The ideology of 
authenticity held that for Aboriginal people, the changes that accompanied modernity took them further away from their 'authentic' selves. For Aboriginal people, modernity was cast as a process of distancing from their own culture" (Raibmon 2005:202).

The workings of such notions of authenticity were at play in connection with the exhibitions in Copenhagen in the late nineteenth and early twentieth centuries as well. The praise of troupes considered to be magnificently authentic and untouched was only surpassed by the heavy critique of lost authenticity the troupes faced when not living up to such standards, and the organisers went to great lengths to try to secure performers for their shows who could pass as authentic and unspoiled (Henningsen 2010).

A central feature in the success of the live ethnographic exhibitions was thus their ability to provide shows which lived up to the expectations of the public, that is, shows of ethnographically interesting, radically different, unchanging people. Such a staging could then be utilised to illustrate what was seen as the distant past of the spectators. The aforementioned Johannes Fabian introduced in 1983 the term denial of coevalness to capture the process in which anthropologists placed the peoples of their studies in another - past - time than the observing anthropologist, thus denying them a place in his or her own present time (Fabian 1983/2002). This process of denial of coevalness was also functioning in the live ethnographic exhibitions in Copenhagen and elsewhere. The shows were informed by theories of evolution and of racial hierarchies, within which the different people on display were considered and placed to represent different stages of human evolution - stages on the way to the pinnacle of development: the contemporary European man (rather than woman) (Andreassen \& Henningsen

2011). Above, we saw an example of such an evolutionarily informed understanding of the Kirghiz and their insufficiently developed ears and eyes. The importance placed on such examples of what was considered less developed and stagnated peoples can be seen in the following excerpt from the popular educational book Naturfolkenes Liv (Life of the Natural Peoples) written in the late nineteenth century by Waldemar Dreyer:

The significance of more thorough knowledge of the natural peoples is [...] that through it we will be able to achieve a deeper insight into [...] the evolutionary history of our own people. One can look outside the realm of our present civilisation to those peoples and tribes unaffected by it, whose life and thoughts can be used as mirror reflections of the evolutionary stages our own predecessors have run through (Dreyer 1898, my translation).

Due to their powerfulclaims of providing ethnographic authenticity, the live ethnographical exhibitions were well suited to popularise and visualise such ideas of human progression and evolution for a broader audience than the scientific community. As historian Pascal Blanchard states in his study of the phenomenon, which he calls "human zoos":

Visitors to the exhibitions had little sophistication. [...] They were encouraged to interpret what they saw as a demonstration of the progress of humanity from savagery to civilization. [...] The entertainment value of the "savage" was increased by activities considered to be primitive in nature, such as dance, music, games and traditional physical pursuits, in which the body of the "savage" was the key element. This body was represented as the reflection of a universe far removed from the technological progress of the West and close to nature, where 
man's survival depended on his physical prowess (Blanchard et al. 2008:24f.).

Again, the bodies of the members of the ethnographic troupes are at the centre of the narrative of radical difference and of temporal displacement offered to the public: A temporal displacement in which the living and very present bodies of different groups of people were considered remnants of the distant pasts, in which these groups were denied coevalness with the spectators and organisers. Within this logic of linear, temporal progress, the various peoples were seen as stagnating at a certain stage and thus exhibitions of examples of "stagnated" people were thought of as instructive in the study of human development. In the following we shall look closer at the somewhat surprising recurrence in Denmark in 2010 of the live exhibition seen as a direct window to our own distant past or "prehistory".

\section{The STAging OF THE "Bushman" EVENT AT LEJRE}

While the human exhibition exists in more benign forms today - that is, the people in them are not displayed against their will - the desire to look upon predictable forms of Otherness from a safe distance persists (Fusco 1994:154).

The Namibian group came to Denmark in connection with a small Stone Age festival in the experimental archaeological park at Lejre in 2010 to which the Ju/'hoansi were invited due to their knowledge and assumed firsthand experience of hunter-gatherer societies.

The site of the event was thus not a zoo or an amusement park but rather a place for popular instruction on the distant Danish and European past through experiments and reenactment. This means that, in contrast to the nineteenth- and twentieth-century exhibitions, the "exotic" people were not the only ones performing - a range of performers and actors of European descent living "prehistoric lives" in the park during the summer were also on stage at Lejre, in attempts to bring selected pasts to life before the audience. The whiff of colonial exploitation and derision so connected with the exhibitions in zoos and amusement parks could thus be avoided by stressing the shared experience of re-enacting the past as a means of popular education and entertainment, rather than the popular education produced in earlier live ethnographic exhibitions which had the effect, in africanist Bernth Lindfors' words, of "pushing whites and blacks further apart by placing them in closer proximity. Africans were put on stage in order to distance them from the rest of humanity" (1999:xii). As a communications officer in the Lejre park explains it:

We are not a museum but a pedagogical activity centre, in which we aim to bring prehistoric man to life in as authentic surroundings as possible and as non-ethnocentric as possible. In that sense, the Ju/'hoansi Bushmen are neither more nor less on display than the rest of the prehistoric families and other historical groups staying in our ironage, Viking and rural milieus. They are all modern communicators of historical knowledge. ${ }^{3}$

The organisers of the "Bushman" event had sent out separate press releases and invitations to the public and to archaeologists and historians beforehand, in which the intentions behind the event were explained and the daily programme listed, including the accompanying ethnographic lectures on "Bushman" issues by the German-Namibian Werner Pfeifer. The email forwarded to me, mentioned in the introduction, was sent to prehistory 
archaeologists with the subject: "Ethnographic journey to Sagnlandet Lejre: from the Danish open air museums to Africa and back" and contained the following description of the event:

In connection with the Stone Age festival 4 Bushmen from Namibia will visit Sagnlandet Lejre [...] They will make camps the Bushman way, perform their traditional trance dances and songs, and will conduct exciting hands-on workshops e.g. on the making of beads from ostrich eggs. It is possible to walk up to them at any point and ask them about their way of life, their rituals and anything you might be interested in, not least academically. ${ }^{4}$

Nowhere in this material or the press release did the names of the Ju/'hoansi appear. In a newspaper report from the event it was, however, revealed that their names were: / Aao Nlaici, Khaum Ilóce and Tciixo Carisa (Information, 31 July 2010). It is telling that the Ju/'hoansi performers were rendered nameless while their companion of German descent was individualised by being named in the programme. This lack of individualisation underscored the logics of typicality prevalent in ethnographic exhibitions, particularly when the Namibian of European descent was being granted status as individual - and expert - by way of being named and given a platform for lecturing on the accompanying "Bushmen" and their way of life.

The Ju/'hoansi performers were not only rendered nameless in the material framing the event, but were also situated in the past - just as Johannes Fabian pointed out when coining the term denial of coevalness. In a television interview one of the organisers of the Stone Age festival stated that " $[w]$ hen we think of our forefathers 6000-7000 years ago, who were hunter-gatherers as well, we have no faces so to speak. But by meeting the Bushmen we can relate to our past" (Matteo Pilati, TV2 Lorry, 27 July 2010, my translation). In the printed press material, the organisers did attempt to convey the message that the Ju/'hoansi were performers re-enacting a past just like the Europeans spending the summer in the park, but at the same time used the present tense (as in the email quoted above) when describing the features of the event, so that the planned activities appeared as if they were in fact ordinary everyday activities of San people rather than staged ones representing past practices. This added to the sense that the visitors from southern Africa were in Denmark not as communicators of historical knowledge, as the organisers otherwise emphasised, but as representatives of people who are living today in ways similar to the distant European past (that is, as hunter-gatherer). And even in a park dedicated to the re-enactment of these distant pasts - rife with people in fanciful leather garments and strange behaviour - the Ju/'hoansi stood out due to their very sparsely dressed and thus very visible brown and petite bodies.

The activities performed by the Ju/'hoansi ranged from jewellery making over skinning of animals and shooting with bows and arrows to song and dance. Not far from the supposedly everyday activities performed by the people on display in the late nineteenth- and early twentieth-century exhibitions, as described earlier by Blanchard. And not too far from the activities performed by the European re-enactors at the Lejre park in 2010 either. But something was different in the way the audience perceived what was displayed before them, according to my observations. Despite the scattered efforts of the organisers and the performers themselves to explain that the event was based on the same principles as the 
rest of the park - popular communication of historical knowledge and practices by way of re-enactment - parts of the audience at least did not receive the message. Several outbursts along the lines of "it's crazy that they still live like this!" (Field notes 2010) could be heard immediately after it had been explained that the performance was a re-enactment of former practices - the staging of the event as real life overshadowed the status of it as re-enactment.

A sense of foreignness and of lack of coevalness thus existed at Lejre just as in the old exhibitions: the framing in the television interview points to such an understanding of the logic of the event. Furthermore, based on my observations of the reactions of the visitors, the performance was perceived by parts of the audience as if they were presented with a view to the practices of a group of people who are still today organising their lives in ways similar to those of the Danish Stone Age, thus providing a rare peek into lived life in the distant past in what is now Denmark.

And this focus on creating a recognisable sense of foreignness and past-ness through the material staging of the event along the lines of what can be called a "Bushman discourse" seems to have trumped the message of reenactment at times attempted conveyed orally by organisers and performers alike during the event itself, if not in the interview on local television and in the use of an ethnographic present tense in the material accompanying the event.

\section{THE POWERFUL INVITATION OF LIVING BODIES IN THE EXHIBITION}

As explained in the introductory parts of this article, both Barbara Kirshenblatt-Gimblett and Eric Ames point to the particularity of living bodies on display: they are seen as "signs of themselves" (Ames) and are understood as "presenting rather than representing" (Kirshenblatt-Gimblett). This is also seen in the Lejre event. When the organiser explains the attraction of the so-called Bushman visit in the television appearance quoted above he points to the meeting with the Ju/'hoansi as a direct way of relating to the Danish past - the audience see the faces and bodies of their supposed forefathers which presumably will enable them to relate to the prehistoric ancestors and their way of life. The logics of denial of coevalness mentioned earlier were thus alive and well with the organisers of the 2010 exhibition, who in the quotation present the living Ju/'hoansi almost as representatives of the prehistoric forefathers of the Danish Stone Age. In combination with what I call "the Bushman invitation" - that is, the framing and staging of the exhibition in terms of the unchanging, authentic, ancient, eternal Bushman - this functions to encourage the audience to understand the performers in the event in the same terms as those in the "exotic" exhibitions a hundred years ago: as radically different and out of (our) time. Again, the bodies of the so-called Bushmen play a significant role. As part of the event, an archery contest was arranged between one of the so-called Bushmen and one of the "regular" European re-enactors, in which they were to use their respective bows and arrows to shoot at a wild hog replica made of plastic. Neither performed particularly well in the shooting, but when the "Bushman" had made his shot a spectator next to me exclaimed with considerable admiration: "You can see that it is not an acquired skill!" - meaning, consequently, that the ability to shoot with bows and arrows is a natural, inherited capability for the Ju/'hoansi archer. The shooting by the European performer did not occasion such exclamations. Thus, 
the "Bushman invitation" and the bodily difference of the performers encouraged particular readings of the event - readings in which a technical skill as refined as archery was translated into bodily capabilities, much like those presented earlier of the "monkey-like dexterity" of the Indian performers at the Zoo in 1901. This connection between the people on display in live ethnographic exhibitions and nature has been pointed to earlier (cf. Pascal Blanchard), and it is prevalent also in general discourses of Bushman-ness. As Steven Robins puts it: “Images of 'bushmen' living close to nature and animal-like, and as the bearers of a lost human essence have subsequently become deeply inscribed in the popular imagination" (Robins 2000:61-62).

And because the staging of the event, as mentioned, did nothing to nuance or destabilise this common perception of so-called Bushmen, it helped support a reading of the living bodies according to this established Bushman discourse. This is not an uncommon phenomenon with reenactment, as anthropologist Mads Daugbjerg has shown in a study of another Danish openair museum making use of re-enactment in its communication of historical knowledge through an edutainment practice. When the framing and staging of the exhibitions reaffirm the existing expectations of the audience it becomes difficult to communicate knowledge that could nuance the common perceptions he calls it a "collaboration" of the organisers with the expectations of the audience (Daugbjerg 2005:10-12).

Aside from the point that the living bodies function as strong communicators of (assumed) authenticity due to their being "signs of themselves", putting living bodies on display is often seen as controversial - given the historical connections to colonialism and creations of scientifically sanctioned racial hierarchies. Events similar to the one in Lejre organised in Germany in 2010 occasioned a critique from scholars and activists that was almost completely lacking in the Danish case. In the Danish and especially Norwegian public there was, however, widespread debate a few years later in 2014 when artists reestablished the so-called Congo-village in Oslo - deliberately mimicking the Congo-village set up in connection with the centenary of the Norwegian constitution in 1914, though importantly - the 2014 version did not contain exhibited living people.

While maintaining the critical attitudes towards some of the effects of such events, one could argue that exhibitions consisting of living human bodies, of persons, of subjects presumably with specific agendas and reasons for participating - potentially can provide platforms for strategic manoeuvring for the people on display, now and in the past.

\section{Political Agendas AND discourses OF INDIGENEITY}

These tribal discourses can, of course, become powerful political and economic resources for subaltern people (Robins 2000:63).

As seen in the section above, many similarities with the old "exotic" exhibitions could be seen at Lejre in 2010 but some significant differences existed as well, having mainly to do with the venue - a park for archaeological instruction and re-enactment and not a zoo or an amusement park - but also with the performers. The group of Ju/'hoansi visiting Lejre were trained performers, who in Namibia are part of an organisation of so-called living museums, established in the mid-2000s with - suitably - considerable inspiration from the Danish experimental park at Lejre. At these 
32 living museums, groups of indigenous peoples cater for, among other things, tourist demands of catching glimpses of to them unknown cultures and ways of living.

Tourism is a major income generator in southern Africa, and it is a political priority in both Namibia and South Africa to strengthen this sector, and cultural tourism in particular, because this form of tourism is regarded as one of the opportunities in which people lacking officially recognised skills, formal training and education may actually succeed in bettering their livelihood (Ministry of Environment and Tourism Namibia 2008; National Department of Tourism South Africa 2011). In Namibia - as in South Africa where initiatives similar to the Namibian living museums have been established - the apartheid system worked on several levels in keeping San peoples - and others marginal politically and economically while simultaneously suppressing their cultural expressions (Gordon 1992, White 1995, Robins 2000). The hope of the post-apartheid governments is that this can be remedied through intensification of cultural tourism, while also facilitating income-generating initiatives.

The organisation The Living Culture Foundation, to which the group performing in Lejre is affiliated, stresses two main aims of the living museums endorsed by the foundation: strengthening of cultural identity and of earned income opportunities among marginalised people such as the San peoples of Namibia today. These aims are expressed explicitly at the official website of the Living Culture Foundation in the following manner:

The main aim of the Living Museum is to give members of a certain language group - and especially children - the possibility to deal with the origins of their culture and thus understand their cultural background. This may contribute to regain of cultural identity. It may help to understand the complicated situation in modern Namibia and could finally help to find solutions for social problems. Another aim of the Living Museum is the creation of an income for poor communities in Namibia. This can be achieved through the tourism industry in Namibia. But not only tourists, also pupils, students and every Namibian can support a Living Museum and learn interactively about the fascinating traditions of the presented culture (Internet source 2).

At the website the Living Culture Foundation provides potentially interested communities with a handbook explaining the aims and methods of setting up a living museum under the auspices of the foundation:

Most of our projects live off the representation of realistic and traditional cultures of Namibian cultures and language groups. The authenticity and credibility of the presentation are of vital importance.

We only support projects, which are - according to research of the specific cultural group - accepted as being authentic. Given that the presented parts of the culture are in fact showing the traditional culture of a certain time and group, the project group will be able to establish a new income opportunity and at the same time prohibit a further loss of their culture. Especially the regain of a new cultural identity can only be achieved if the original culture is presented as authentic as possible (Internet source 3).

This "Bushman discourse" of the cultural tourism business, including the living museums and similar enterprises, is informed by the preexisting assumptions and notions of "Bushmanness" that over the last decade have been heavily criticised by scholars and activists. 
PERFORMANCE AND POLITICS OF AUTHENTICITY IN LIVE ETHNOGRAPHIC EXHIBITIONS

How to handle this uncomfortable situation as a critical academic? As Steven Robins asks:

...how should anthropologists respond when tribal histories and fantasies are no longer manufactured by anthropologists and colonial administrators, but rather by "the natives" themselves? How should anthropologists respond to re-inventions and reappropriations of colonial discourses on African tribes and traditions by subaltern people in pursuit of their own self-defined political objectives and agendas? What if the traditions that are being invented "from below" end up replicating and mimicking the very anthropological traditions and colonial discourses that [academics and activists] have so vigorously attacked? (Robins 2000:59).

Robins further suggests that the narrow scholarly focus on critical deconstructions of the colonial discourses miss important insights into the social and political manoeuvring of the San people, that the anti-essentialist stance of the academics fails to grasp the political strategies of the San people which can be strengthened by invocation of "Bushman" myths (Robins 2000:66). In accordance with the logics of community building behind enterprises such as the living museums in Namibia, Robins states that such manoeuvrings should not be seen as necessarily only strategic and instrumental in political struggles for recognition and rights but also in recovering social memory previously suppressed (Robins 2000:73).

There is a strict code of conduct connected to the living museums, which the communities must live up to in order to be affiliated with the larger organisation behind. But this practice of performing according to an established "Bushman discourse" or of extending a stereotypical "Bushman invitation" to the audience can potentially be valuable in the (identity-)political projects of the participating

\section{SUBJECTS TURNED OBJECTS - WHILE (RE)CLAIMING SUBJECTIVITY}

Revisionist critics have argued that the primordialist discourse represents the distortion and consumption of Bushman culture by the Western metropole. Yet, if the icon of the original forager is at least partially a Western construct, as has been argued so forcefully, then ironically it would appear as if it is the Bushmen who are doing the consuming here, in appropriating a Western trope as the organising principle of their own rhetoric of identity (White 1995:55).

Barbara Kirshenblatt-Gimblett points to the particular feature of living human bodies on display that they are seen by audiences to present rather than represent, and Eric Ames writes about the bodies seen as "living breathing signs of themselves". This is besides all forms of coercion, maltreatment and affiliations with colonialism - part of what makes living human bodies on display controversial through the powerful message sent to their audiences. But it might also be the reason why these practices can contain the double move of subjectivation through objectivation described above in connection with the political projects of the participating marginalised groups, because they are centred on living bodies cast as inherently different from the audiences. Paige Raibmon has shown how Native Americans in the nineteenth century used the live ethnographic exhibitions as platforms for claiming (political) subjectivity in a system of marginalisation and colonial exploitation (Raibmon 2005) and Cathrine Baglo's studies of exhibitions of Sami people (see for example Baglo 2014) have also contributed to creating a more nuanced 
34 understanding of the agendas of the people on display. Likewise it was an ambition from the beginning of the collaborative research project on the exhibitions in Copenhagen around the end of the nineteenth century that we would look for the agency of the people on display even within the coercive power structures of the exhibitions and despite the scarcity of written sources from the exhibited people themselves (Henningsen 2010, Andreassen \& Henningsen 2011). In the same way, the Lejre event and the tourist sites and living museums can provide an arena for subjectivation through objectivation for marginalised people with limited political and economic possibilities, even if it does come at a price due to the narrow discursive field of "authentic" operation activated by and through the performances.

And perhaps this is one of the reasons why the cultural tourism business is also a powerful political strategy for what is now often called "first nation peoples"? Their abstract claims to special rights based on their status as endangered cultures/peoples becomes concrete and tangible through visualisation practices, often with heavy emphasis on bodily differences and features. They are seen as having special access to the practices about to disappear, and this special access can be translated into special rights and resources.

\section{Powerful strategic}

\section{RE-APPROPRIATION WITH MULTIPLE AND AMBIVALENT EFFECTS}

The re-appropriation of colonial discourses in cultural tourism does, however, come at a price according to anthropologist Hylton White:

If [the "Bushman"] identity strategy is based on the market value of the heritage they claim as their own, then this has three related implications. Firstly, the market value of this heritage and thus of the Bushmen themselves is derived from the popular authority of the Bushman discourse [...]. They have no means of controlling that discourse and are thus bound to its representations. Secondly, and in consequence of this parameter, they are unable to introduce political or economic considerations into the public realm since these are dissonant with the Bushman icon. Hence the Kagga Kamma [a "Bushman" tourism site] management's assertion that if they wish to live like Bushmen they should have no consumer goods. Thirdly, and also as a result of the same discursive limitation, they find it extremely difficult to generate the appearance of seamless authenticity in what is an essentially impossible mould (White 1995:55).

The Ju/'hoansi trip to Denmark can thus be seen as part of a political strategy, in which external acknowledgement of the value and significance of their culture plays a significant role, but through the mimicking of the existing perceptions of authentic "Bushman-ness", the cultural performers at such tourist sites and living museums reproduce and maintain an understanding of indigeneity with a very limited room for manoeuvring. And this combined with the lack of recognition of the similarities with the previous live ethnographic exhibitions is why, despite the above assertion of political potentiality connected to events such as the one at Lejre, I still remain critical towards it. My scepticism stems largely from the staging of the event and its reception in the Danish public. The powerful invitation of the living bodies - supported by the staging according to the pristine-and-eternal-hunterand-gatherer discourse - seemed to be trumping the spoken and written words of the organisers pointing to the Ju/'hoansi as communicators of historical knowledge just like the other performers at Lejre. 
Stereotypes are powerful and can thus be used by the Ju/'hoansi as well as by the organisers at Lejre in order to attract an audience, but they are also limiting and can thus send a message of lack of coevalness of the $\mathrm{Ju} /$ 'hoansi performers and keep them within a narrow field of discursive practice that is then seen as the proper way to be Ju/'hoansi. Alongside critical academics and activists, I may feel uncomfortable when living humans are put on stage as "signs of themselves" in accordance with stereotypical understandings of their authentic nature and practices and not as actors or artists or the like - but in the case of the Ju/'hoani at Lejre, they are re-enacting. Due to the framing and staging of the event, which has been criticised above, the audience may have a hard time grasping this, which is unfortunate in terms of the event being part of a popular education scheme, but seen from the Ju/'hoansi side that might not be the prime concern. Survival, income, rights, resources and rebuilding of a cultural identity suppressed during the apartheid years might weigh heavier. It is after all precisely the living bodies of the Ju/'hoansi that are on stage - and at stake.

\section{Notes}

1. This work was supported by The Danish Research Council for Culture and Communication.

2. Private correspondence, 23 July 2010, my translation.

3. Private correspondence, 12 October 2010, my translation.

4. Private correspondence, 23 July 2010, my translation.

\section{INTERNET SOURCES}

1. www.sagnlandet.dk (accessed 2 December 2012)
2. http://www.lcfn.info/concept/project-conception (accessed 25 January 2015)

3. http://www.lcfn.info/concept/developmentprinciples (accessed 25 January 2015)

\section{LITERATURE}

Ames, Eric 2008. Carl Hagenbeck's Empire of Entertainment. Seattle: University of Washington Press.

Andreassen, Rikke \& Anne Folke Henningsen 2011. Menneskeudstilling. Fremvisninger af eksotiske mennesker i Zoologisk Have og Tivoli. [Human Exhibition. Display of Exotic People in the Zoological Gardens and Tivoli.] Copenhagen: Tiderne Skifter.

Baglo, Cathrine 2014. Rethinking Sami Agency during Living Exhibitions. From the Age of Empire to the Postwar World. Nebraska: University of Nebraska Press.

Blanchard, Pascal, Nicolas Bancel, Gilles Boëtsch, Eric Deroo, Sandrine Lemaire \& Charles Forsdick (eds.) 2008. Human Zoos. Science and Spectacle in the Age of Empire. Liverpool: Liverpool University Press.

Clifford, James 1988. The Predicament of Culture. Twentieth-Century Ethnography, Literature, and Art. Cambridge: Harvard University Press.

Daugbjerg, Mads 2005. "De gode gamle dage genoplivet! Frilandsmuseerne og spillet om fortiden." [The good old days revived! Open air museums and the play for the past.] Nordisk Museologi 1, 3-14.

Dreyer, Waldemar 1898. Naturfolkenes Liv. Populoer Ethnografi. [Life of the Natural Peoples: Popular Ethnography.] Copenhagen: Frem.

Dreyer, Waldemar 1900. "Kirgiserne i Zoologisk Have." [Kirghiz in the Zoo.] Politiken 25 August, 1900.

Fabian, Johannes 1983/2002. Time and the Other. How Anthropology Makes Its Object. New York: Columbia University Press. 
Fillitz, Thomas \& A. Jamie Saris 2012. Debating Authenticity. Concepts of Modernity in Anthropological Perspective. New York, Oxford: Berghahn Books.

Fusco, Coco 1994. "The other history of intercultural performance." TDR 38:1, 143-167.

Garland-Thompson, Rosemarie (ed.) 1996. Freakery. Cultural Spectacles of the Extraordinary Body. New York: NYU Press.

Gordon, Robert 1992. The Bushman Myth and the Making of a Namibian Underclass. Boulder: Westview Press.

Henningsen, Anne Folke 2009. "Producing and consuming foreignness. 'Anthropologicalzoological' exhibitions in Copenhagen.' In Anne Folke Henningsen, Leila Koivunen \& Taina Syrjämaa (eds.). Nordic Perspective on Encountering Foreignness. Turku: University of Turku, 55-70.

Henningsen, Anne Folke 2010. “De/stabilising Otherness. Acts of subversion, transgression and apporpriation in Live ethnographic exhibitions." Ethnologia Scandinavica: A Journal for Nordic Ethnology 40, 5-15.

Kirshenblatt-Gimblett, Barbara 1998. Destination Culture. Tourism, Museums, and Heritage. Berkeley: University of California Press.

Lindfors, Bernth (ed.) 1999. Africans on Stage. Studies in Ethnological Show Business. Bloomington: University of Indiana Press.
Ministry of Environment and Tourism 2008. National Policy on Tourism for Namibia. Windhoek: Directorate of Tourism.

Moustache (pseudonym) 1901. "Fra Zoologisk Have." [From the Zoo.] Politiken 6 July, 1901.

National Department of Tourism South Africa. 2011. National Tourism Sector Strategy. Pretoria: National Department of Tourism.

Raibmon, Paige 2005. Authentic Indians. Episodes of Encounter from the Late Nineteenth-Century Northwest Coast. Durham: Duke University Press. Robins, Steven 2000. "Land struggles and the politics and ethics of representing 'Bushman' history and identity" Kronos: Journal of Cape History 26, 56-75.

White, Hylton 1995. In the Tradition of the Forefathers. Bushman Traditionality at Kagga Kamma. Cape Town: University of Cape Town Press.

Anne Folke Henningsen, Ph.D., Associate

Professor of Ethnology

folke@hum.ku.dk

Saxo Institute, University of Copenhagen

Karen Blixens Plads 8

DK-2300 Copenhagen, Denmark 